\title{
Protein Wnt-16
}

National Cancer Institute

\section{Source}

National Cancer Institute. Protein Wnt-16. NCI Thesaurus. Code C102967.

Protein Wnt-16 (365 aa, $\sim 41 \mathrm{kDa}$ ) is encoded by the human WNT 16 gene. This protein is involved in lig and-dependent signaling. 